Perbedaan Pengaruh Metode Latihan dengan Bola Diam dan Bola Bergerak terhadap Ketepatan Shooting Sepakbola pada Pemain Putra Usia 10-12 Tahun SSB Bina Pratama Sragen Tahun 2020

(Adika Sukmawati ; Agus Supriyoko ; Fatkhul Imron)

\title{
PERBEDAAN PENGARUH METODE LATIHAN DENGAN BOLA DIAM DAN BOLA BERGERAK TERHADAP KETEPATAN SHOOTING SEPAKBOLA PADA PEMAIN PUTRA USIA 10-12 TAHUN SSB BINA PRATAMA SRAGEN TAHUN 2020
}

\author{
Adika Sukmawati ${ }^{1}$, Agus Supriyoko ${ }^{2}$, Fatkhul Imron ${ }^{3}$ \\ adika.sukmawati@gmail.com \\ ${ }^{123}$ Universitas Tunas Pembangunan Surakarta
}

\begin{abstract}
ABSTRAK
Tujuan dari penelitian ini adalah untuk mengetahui : (1) Perbedaan pengaruh metode latihan dengan bola diam dan latihan dengan bola bergerak terhadap ketepatan shooting sepakbola pada pemain putra usia 10-12 tahun SSB Bina Pratama Sragen, (2) Manakah metode latihan yang lebih baik antara latihan menggunakan bola diam dengan latihan menggunakan bola bergerak terhadap ketepatan shooting sepakbola pada pemain putra usia 10-12 tahun SSB Bina Pratama Sragen.

Metode penelitian ini menggunakan metode eksperiment. Populasi dalam penelitian ini adalah pemain putra usia 10-12 tahun SSB Bina Pratama yang berjumlah 33 orang. Sampel yang digunakan adalah 30 pemain putra usia 10-12 tahun. Teknik sampling penelitian ini menggunakan purposive sampling. Teknik pengumpulan datanya ialah dengan pretest-posttest dimana bola diam dan bola bergerak merupakan variabel bebas sedangkan ketepatan shooting sebagai variabel terikat. Analisis data menggunakan: (1) Uji reliabilitas, (2) Uji normalitas, (3) Uji homogenitas, (4) Uji hipotesis dengan bantuan aplikasi SPSS versi 26.0 .

Penelitian ini menghasilkan simpulan sebagai berikut: (1) Ada perbedaan pengaruh yang signifikan antara metode latihan dengan bola diam dan latihan dengan bola bergerak terhadap ketepatan shooting sepakbola pada pemain putra usia 10-12 tahun SSB Bina Pratama Sragen tahun 2020. ( $t_{\text {hitung }}-3,308<t_{\text {tabel }}$ 2,000 maka $\mathrm{H}_{\mathrm{a}}$ diterima ). (2) Metode latihan shooting dengan bola diam lebih baik daripada latihan dengan bola bergerak terhadap ketepatan shooting sepakbola pada pemain putra usia 10-12 tahun SSB Bina Pratama Sragen tahun 2020. (Metode latihan dengan bola diam mengalami peningkatan sebesar $9,6 \%$, sedangkan bola bergerak hanya mengalami peningkatan sebesar 6,3\% ).
\end{abstract}

Kata kunci: Latihan Bola Diam, Latihan Bola Bergerak, Ketepatan Shooting

\section{PENDAHULUAN}

Dalam bahasa Inggris sepakbola disebut Football, sedangkan di Amerika Serikat disebut Soccer. Sepakbola memiliki kemampuan menantang seperti yang Jurnal IImiah SPIRIT, ISSN; 1411-8319 Vol. 21 No. 1 Tahun 2021 
Perbedaan Pengaruh Metode Latihan dengan Bola Diam dan Bola Bergerak terhadap Ketepatan Shooting Sepakbola pada Pemain Putra Usia 10-12 Tahun SSB Bina Pratama Sragen Tahun 2020

(Adika Sukmawati ; Agus Supriyoko ; Fatkhul Imron)

dikemukakan Joseph A. Luxbacher (2011:5) bahwa, “ Sepakbola adalah permainan yang menantang secara fisik dan mental". Sepakbola merupakan olahraga beregu yang memiliki tujuan untuk mencetak tendangan bola ke dalam gawang lawan sebanyak-banyaknya. Seorang pemain harus memiliki kemampuan untuk menguasai teknik dasar sepakbola baik secara individu maupun secara tim agar mendukung penampilannya saat bertanding. Penguasaan teknik yang baik merupakan prasyarat untuk menjadi pemain sepakbola yang handal. Menurut Sutrisno \& Khafadi (2010:2) menyatakan bahwa, "Pada dasarnya teknik dasar sepakbola diantaranya menendang, mengontrol, menyundul, dan menggiring bola". Teknik dasar sepakbola sendiri meliputi : menendang bola (kicking), mengontrol bola (stoping), menggiring bola (dribbling), menyundul bola (heading), menjaga gawang, merampas bola (tacling) dan lemparan ke dalam (trow-in).

Dalam permainan sepakbola teknik dasar yang sering digunakan ialah teknik menendang (kicking) karna memiliki peluang yang besar untuk : mengoper (passing) bola kepemain lainnya, menembak (shooting) ke gawang, membersihkan (clearing) dan tendangan-tendangan khusus. Dari tendangantendangan tersebut dilakukan dalam kondisi atau situasi yang berbeda. Sebagai contoh : apabila bola berada di area pertahanan lawan maka memiliki tujuan untuk melakukan tendangan menembak (shooting) ke gawang lawan agar memperoleh nilai (gol). Sedangkan ketika bola di area pertahanan sendiri maka akan dilakukan tendangan membersihkan (clearing) atau mengoper (passing) untuk menyelamatkan daerah pertahanan sendiri.

Permainan sepakbola ini harus dimainkan oleh dua tim yang berada di atas tanah lapang yang luas. Dalam setiap tim ada sebelas pemain dimana satu diantaranya sebagai penjaga gawang. Secara umum hanya penjaga gawang saja yang diperbolehkan untuk menyentuh bola dengan tangan, dan sepuluh pemain lainnya hanya diperbolehkan menendang bola dengan kaki, mengontrol bola dengan dada, dan kepala untuk menyundul bola. 
Perbedaan Pengaruh Metode Latihan dengan Bola Diam dan Bola Bergerak terhadap Ketepatan Shooting Sepakbola pada Pemain Putra Usia 10-12 Tahun SSB Bina Pratama Sragen Tahun 2020

(Adika Sukmawati ; Agus Supriyoko ; Fatkhul Imron)

Menurut Ina Hasanah (2019:52) menyatakan, "Shooting sangat diperlukan dan berpengaruh terhadap laju arah bola. Teknik shooting ini harus sering dilatih karena dapat menentukan arah tendangan yang kita inginkan pada saat menendang". Untuk mengembangkan keterampilan ketepatan shooting dapat dilakukan dengan baik dan benar melalui latihan tembakan-tembakan yang nyata. Yang kemudian akan mempengaruhi kemampuan dari pemain tersebut. Upaya dalam meningkatkan ketepatan shooting sepak bola ialah dengan latihan menggunakan bola diam dan boola bergerak yang kemudian bola tersebut ditendang ke dalam gawang.

Latihan dengan shooting bola ke dalam gawang menggunakan cara bola diam yaitu bola diletakkan di depan gawang yang kira-kira jaraknya kurang lebih 10-15 meter dari bibir gawang. Sedangkan latihan shooting dengan menggunakan bola bergerak yaitu diawali dengan bola digiring (dribbling) lalu sebelum memasuki daerah gawang bola harus ditembak ke arah gawang. Tendangan shooting ini dapat dilakukan dari arah mana saja, dari kanan, dari kiri maupun dari tengah. Namun tendangan shooting tersebut belum diketahui dari arah mana shooting yang paling memiliki pengaruh terhadap peningkatkan kemampuan ketepatan shooting.

Pengertian mengenai latihan disampaikan oleh Afriwandi (2009:3) dalam Wahyu fajar Ihtiarini (2017:117) yang menyatakan, "Latihan adalah serangkaian aktivitas fisik yang terstruktur dan berirama dengan intensitas tertentu dalam jangka tertentu untuk meningkatkan kebugaran jasmani". Latihan shooting dengan bola diam dan bola bergerak ke dalam gawang dari berbagai arah juga memiliki kelemahan dan kelebihan tersendiri. Oleh karena itu untuk mengetahui pengaruh tendangan shooting ke dalam gawang dengan menggunakan latihan bola diam dan bola bergerak perlu untuk dikaji dan diteliti guna menemukan kelebihan dari perbedaan kedua latihan tersebut secara praktik maupun secara teoritis. 
Perbedaan Pengaruh Metode Latihan dengan Bola Diam dan Bola Bergerak terhadap Ketepatan Shooting Sepakbola pada Pemain Putra Usia 10-12 Tahun SSB Bina Pratama Sragen Tahun 2020

(Adika Sukmawati ; Agus Supriyoko ; Fatkhul Imron)

Disebuah salah satu Sekolah Sepakbola (SSB) Bina Pratama Sragen terdapat pembinaan olahraga putra anak usia dini hingga remaja dalam bidang sepakbola. Pada pemain putra usia 10-12 tahun SSB Bina Pratama Sragen dalam latihan maupun dalam kejuaraan masih seringkali melakukan kesalahan dalam tendangan shooting bola ke area gawang lawan, yang ini dapat menyebabkan kerugian bagi tim Bina Pratama Sragen tersebut. Dengan memberikan latihan tendangan shooting ke arah gawang secara berulang-ulang dapat membuat pemain memiliki peningkatan ketepatan dalam menembak bola menjadi lebih baik. Menembak bola ke arah gawang dengan bola dalam keadaan diam dan bergerak dapat dijadikan acuan untuk mengetahui perbedaan dari pengaruh latihan tendangan shooting ke dalam gawang.

\section{METODE PENELITIAN}

Metode yang digunakan dalam penelitian ini yaitu metode eksperimen. Menurut Ali Maksum (2000:65) berpendapat bahwa, "Metode eksperimen adalah penelitian yang dilakukan secara ketat untuk mengetahui hubungan sebab dan akibat diantara variabel. Salah satu ciri utama dari penelitian eksperimen adalah adanya perlakuan (treatment) yang dikenakan kepada subjek atau objek penelitian".

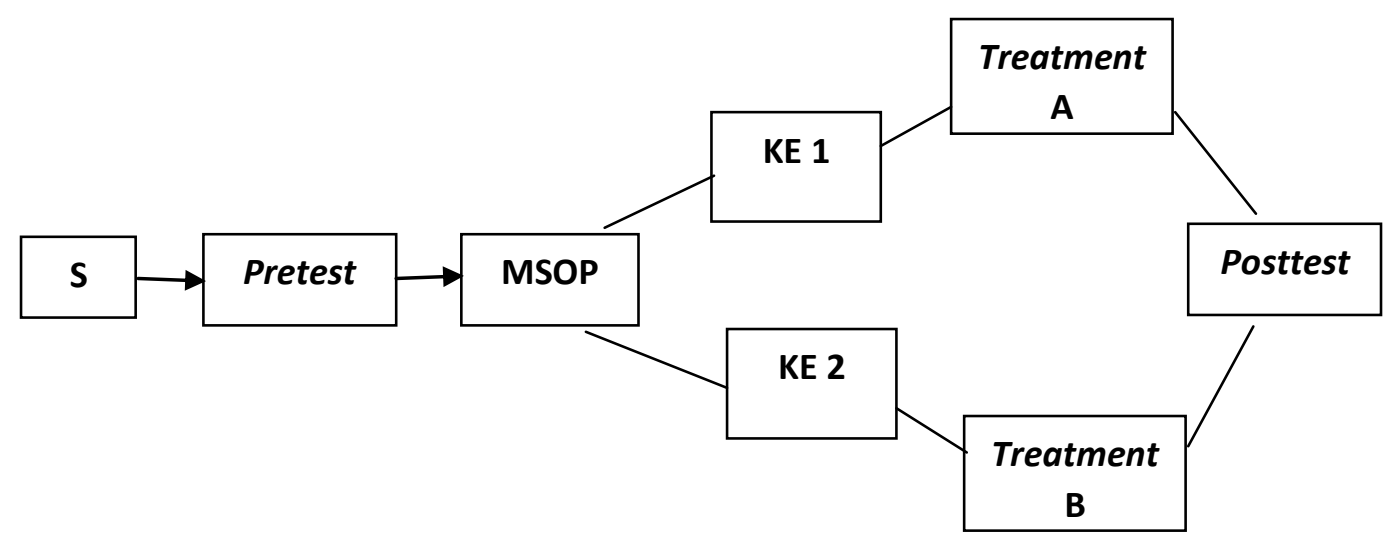

Gambar . 8. Rancangan Penelitian

(Sugiyono, 2007:32 )

Keterangan:

$\mathrm{S} \quad=$ Subjek

Jurnal IImiah SPIRIT, ISSN; 1411-8319 Vol. 21 No. 1 Tahun 2021 
Perbedaan Pengaruh Metode Latihan dengan Bola Diam dan Bola Bergerak terhadap Ketepatan Shooting Sepakbola pada Pemain Putra Usia 10-12 Tahun SSB Bina Pratama Sragen Tahun 2020

(Adika Sukmawati ; Agus Supriyoko ; Fatkhul Imron)

Pretest = Tes awal kemampuan shooting sepakbola

MSOP = Matched Subject Ordinal Pairing

KE $1=$ Kelompok 1

KE $2=$ Kelompok 2

Treatment $\mathrm{A}=$ Latihan shooting dengan bola diam

Treatment B = Latihan shooting dengan bola bergerak

Posttest $\quad=$ Tes akhir kemampuan shooting sepak bola

Pembagian kelompok dalam penelitian ini dengan cara Ordinal Pairing.

Adapun teknik pembagian kelompok secara Ordinal Pairing yaitu:

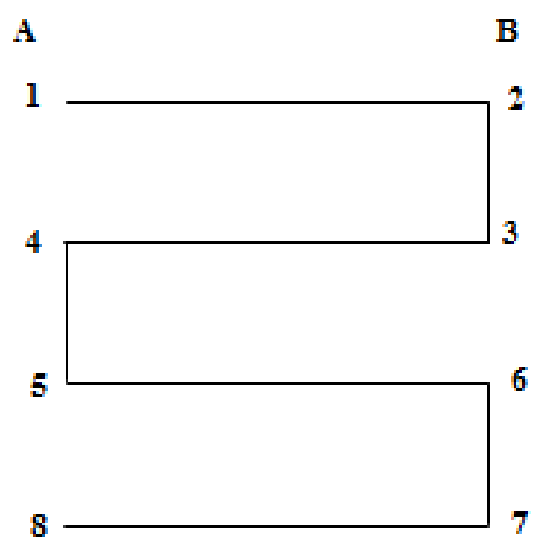

Gambar. 9. Ordinal Pairing

( Sutrisno Hadi, 1995:485)

\section{HASIL PENELITIAN}

\section{Hasil Deskriptif Data Penelitian}

Hasil penelitian "Perbedaan Pengaruh Latihan dengan Bola Diam dan Bola Bergerak terhadap Ketepatan Shooting Sepakbola pada Pemain Putra Usia 10-12 Tahun SSB Bina Pratama Sragen Tahun 2020" dideskripsikan sebagai berikut :

a. Pretest dan Posttest Shooting dengan Metode Bola Diam Hasil pretets dan posttest shooting di SSB Bina Pratama Sragen setelah diberikan treatment latihan bola diam sebagai berikut : 
Perbedaan Pengaruh Metode Latihan dengan Bola Diam dan Bola Bergerak terhadap Ketepatan Shooting Sepakbola pada Pemain Putra Usia 10-12 Tahun SSB Bina Pratama Sragen Tahun 2020

(Adika Sukmawati ; Agus Supriyoko ; Fatkhul Imron)

Tabel 2. Pretest dan posttets shooting dengan metode bola diam

\begin{tabular}{|c|l|c|c|c|}
\hline No & \multicolumn{1}{|c|}{ Nama } & Pretest & Posttest & Selisih \\
\hline 1 & Okta Rio F & 26 & 27 & 1 \\
\hline 2 & Dava Revani & 24 & 26 & 2 \\
\hline 3 & Zidan Adi T & 24 & 27 & 3 \\
\hline 4 & Kevin Budi S & 24 & 27 & 3 \\
\hline 5 & Aldo Saputra & 24 & 25 & 1 \\
\hline 6 & Rizki Hidayat & 23 & 25 & 2 \\
\hline 7 & S. Galih S & 23 & 27 & 4 \\
\hline 8 & Yusuf Ali B & 22 & 23 & 1 \\
\hline 9 & M kholiq & 22 & 24 & 2 \\
\hline 10 & Akmaliansyah & 21 & 24 & 3 \\
\hline 11 & Irul Baskoro & 21 & 22 & 1 \\
\hline 12 & Zainal Abidin & 20 & 23 & 3 \\
\hline 13 & Faiz Munabi & 20 & 21 & 1 \\
\hline 14 & Iqbal Yulianto & 20 & 23 & 3 \\
\hline 15 & Dava Setiawan & 19 & 21 & 2 \\
\hline
\end{tabular}

Berdasarkan tabel 2 di atas, deskriptif statistik pretest dan posttest ketepatan shooting bola ke gawang pada pemain putra usia 10-12 tahun SSB Bina Pratama Sragen setelah diberikan latihan bola diam disajikan pada tabel 3 sebagai berikut :

Tabel 3. Deskripsi Statistik Metode Latihan Bola Diam

\begin{tabular}{|l|l|l|}
\hline Statistik & Pretest & Posttest \\
\hline$N$ & 15 & 15 \\
\hline Minimum & 19 & 21 \\
\hline Maximum & 26 & 27 \\
\hline Sum & 333 & 365 \\
\hline Mean & 22,20 & 24,33 \\
\hline Std. Deviation & 2,007 & 2,160 \\
\hline
\end{tabular}

Berdasarkan tabel 3 di atas, deskriptif statistik pretest dan posttest ketepatan shooting pada pemain putra usia 10-12 tahun SSB Bina Pratama Sragen setelah diberikan latihan bola diam dapat disajikan pada gambar sebagai berikut :

Jurnal IImiah SPIRIT, ISSN; 1411-8319 Vol. 21 No. 1 Tahun 2021 
Perbedaan Pengaruh Metode Latihan dengan Bola Diam dan Bola Bergerak terhadap Ketepatan Shooting Sepakbola pada Pemain Putra Usia 10-12 Tahun SSB Bina Pratama Sragen Tahun 2020

(Adika Sukmawati ; Agus Supriyoko ; Fatkhul Imron)

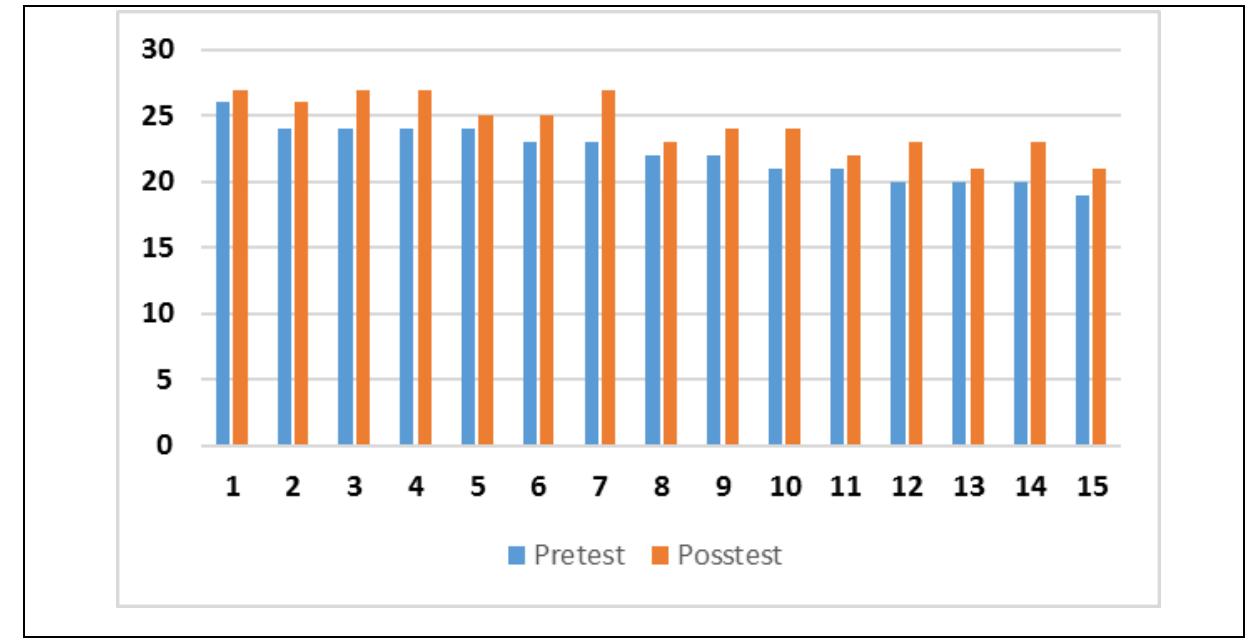

Gambar 10. Grafik pretest-posttest ketepatan shooting bola diam

Dari tabel di atas dapat diketahui bahwa sebelum diberi perlakuan ratarata ketepatan shooting sepakbola pada kelompok latihan bola diam yaitu 22,20 , sedangkan setelah mendapatkan perlakuan memiliki rata-rata 24,33 .

b. Pretest dan Posttest Shooting dengan Metode Bola Gerak

Hasil pretets dan posttest shooting di SSB Bina Pratama Sragen setelah diberikan treatment latihan bola gerak sebagai berikut :

Tabel 4. Pretest dan posttets shooting dengan metode bola gerak

\begin{tabular}{|c|l|c|c|c|}
\hline No & \multicolumn{1}{|c|}{ Nama } & Pretest & Posttest & Selisih \\
\hline 1 & Ivan Ibrahim & 25 & 27 & 2 \\
\hline 2 & Dimas Wahyu & 25 & 26 & 1 \\
\hline 3 & Febri Setyo L & 24 & 26 & 2 \\
\hline 4 & Al Fatih & 23 & 24 & 1 \\
\hline 5 & Dimas Prakoso & 23 & 26 & 3 \\
\hline 6 & Maikal Yusuf A & 23 & 25 & 2 \\
\hline 7 & Rafli Arjuna & 23 & 23 & 0 \\
\hline 8 & Faiz Syahputra & 22 & 24 & 2 \\
\hline 9 & Davitra G B & 21 & 21 & 0 \\
\hline 10 & Latif P S & 21 & 23 & 2 \\
\hline 11 & Angger I L & 21 & 22 & 1 \\
\hline 12 & Fakih Ramadan & 20 & 21 & 1 \\
\hline 13 & Fahri Dian & 20 & 22 & 2 \\
\hline 14 & Rafika R & 20 & 21 & 1 \\
\hline 15 & Aji Eko P & 19 & 20 & 1 \\
\hline
\end{tabular}

Jurnal IImiah SPIRIT, ISSN; 1411-8319 Vol. 21 No. 1 Tahun 2021 
Perbedaan Pengaruh Metode Latihan dengan Bola Diam dan Bola Bergerak terhadap Ketepatan Shooting Sepakbola pada Pemain Putra Usia 10-12 Tahun SSB Bina Pratama Sragen Tahun 2020

(Adika Sukmawati ; Agus Supriyoko ; Fatkhul Imron)

Berdasarkan tabel 4 di atas, deskriptif statistik pretest dan posttest ketepatan shooting bola ke gawang pada pemain putra usia 10-12 tahun SSB Bina Pratama Sragen setelah diberikan latihan bola gerak disajikan pada tabel 5 sebagai berikut :

Tabel 5. Deskripsi Statistik Metode Latihan Bola Gerak

\begin{tabular}{|l|l|l|}
\hline Statistik & Pretest & Posttest \\
\hline$N$ & 15 & 15 \\
\hline Minimum & 19 & 20 \\
\hline Maximum & 25 & 27 \\
\hline Sum & 330 & 351 \\
\hline Mean & 22,00 & 23,40 \\
\hline Std. Deviation & 1,890 & 2,230 \\
\hline
\end{tabular}

Berdasarkan tabel 5 di atas, deskriptif statistik pretest dan posttest ketepatan shooting pada pemain putra usia 10-12 tahun SSB Bina Pratama Sragen setelah diberikan latihan bola gerak dapat disajikan pada gambar sebagai berikut :

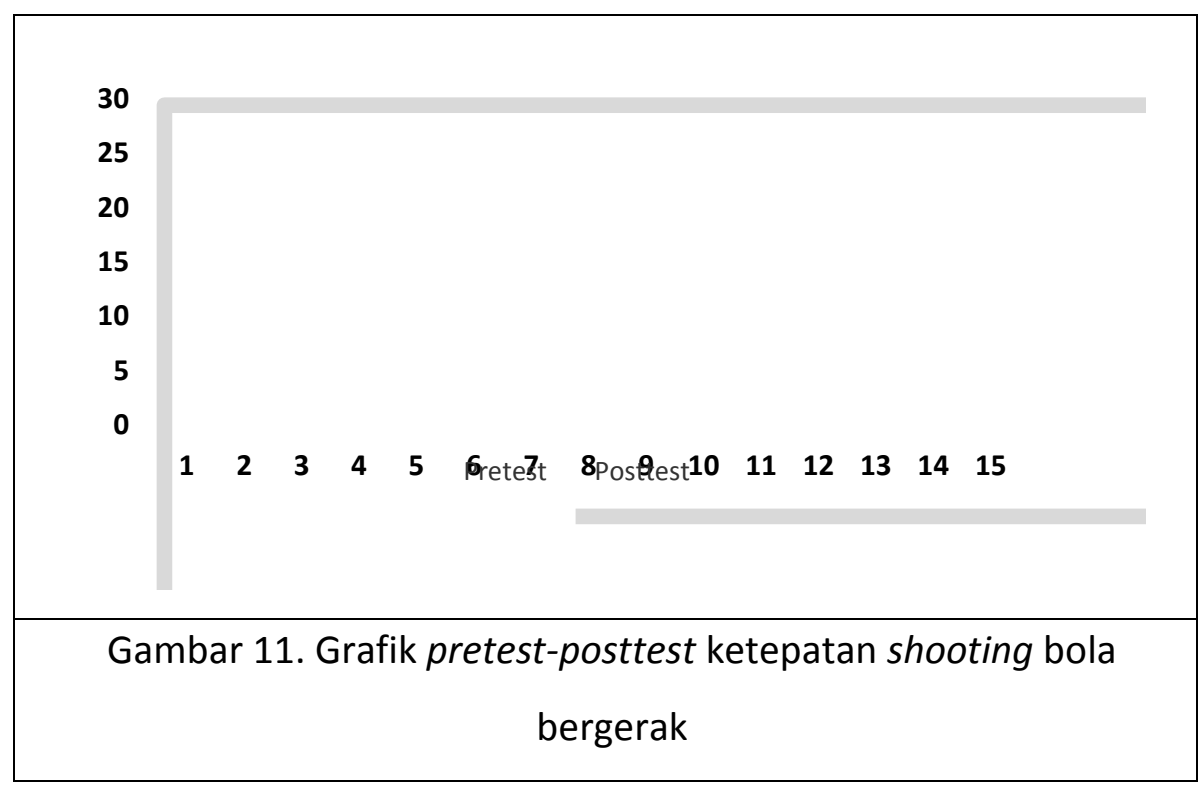

Dari tabel di atas dapat diketahui bahwa sebelum diberi perlakuan ratarata ketepatan shooting sepakbola pada kelompok latihan bola gerak yaitu 22,00 , sedangkan setelah mendapatkan perlakuan memiliki rata-rata 23,40. 
Perbedaan Pengaruh Metode Latihan dengan Bola Diam dan Bola Bergerak terhadap Ketepatan Shooting Sepakbola pada Pemain Putra Usia 10-12 Tahun SSB Bina Pratama Sragen Tahun 2020

(Adika Sukmawati ; Agus Supriyoko ; Fatkhul Imron)

\section{Uji Reliabilitas}

Uji reliabilitas bertujuan untuk mengetahui tingkat keajegan hasil tes yang dilakukan dalam penelitian. Hasil uji reliabilitas tes dan re-test ketepatan shooting sepakbola dapat dikategorikan dengan menggunakan pedoman dari Book Walter Mulyono Biyakto Atmojo (2008:22), yaitu :

Tabel 6. Range Kategori Reliabilitas

\begin{tabular}{|c|c|}
\hline Kategori & Reliabilitas \\
\hline Tinggi Sekali & $0,90-1,00$ \\
\hline Tinggi & $0,80-0,89$ \\
\hline Cukup & $0,60-0,79$ \\
\hline Kurang & $0,40-0,59$ \\
\hline Tidak Signifikan & $0,00-0,39$ \\
\hline
\end{tabular}

Hasil uji reliabilitas data ketepatan shooting sepakbola pada penelitian ini adalah :

Tabel 7. Ringkasan Hasil Uji Reliabilitas Data

\begin{tabular}{|c|c|c|}
\hline Variabel & Reliabilitas & Kategori \\
\hline $\begin{array}{c}\text { Ketepatan Shooting } \\
\text { Sepakbola }\end{array}$ & 0,755 & Cukup \\
\hline
\end{tabular}

\section{Hasil Uji Prasyarat Analisis Data}

a. Uji Normalitas

Uji normalitas dimaksudkan untuk mengetahui apakah variabelvariabel dalam penelitian mempunyai sebaran distribusi normal atau tidak. Penghitungan uji normalitas ini menggunakan rumus Kolmogorov-Smirnov Z. Dengan pengolahan menggunakan bantuan komputer program SPSS 26. Hasilnya disajikan pada tabel 8 sebagai berikut : 
Perbedaan Pengaruh Metode Latihan dengan Bola Diam dan Bola Bergerak terhadap Ketepatan Shooting Sepakbola pada Pemain Putra Usia 10-12 Tahun SSB Bina Pratama Sragen Tahun 2020

(Adika Sukmawati ; Agus Supriyoko ; Fatkhul Imron)

Tabel 8. Rangkuman Hasil Uji Normalitas

\begin{tabular}{|l|c|c|c|}
\hline \multicolumn{1}{|c|}{ Kelompok } & P & Sig & Keterangan \\
\hline Pretest shooting bola diam & 0,455 & 0,05 & Normal \\
\hline Posttest shooting bola diam & 0,122 & 0,05 & Normal \\
\hline Pretest shooting bola gerak & 0,326 & 0,05 & Normal \\
\hline Posttest shooting bola gerak & 0,331 & 0,05 & Normal \\
\hline
\end{tabular}

Dari hasil tabel di atas dapat dilihat bahwa semua data memiliki nilai $\mathrm{p}$ (Sig.) > 0.05, maka variabel berdistribusi normal. Karena semua data berdistribusi normal maka analisis dapat dilanjutkan dengan statistik parametrik.

b. Uji Homogenitas

Uji homogenitas berguna untuk menguji kesamaan sampel seragam atau tidak varian sampel yang diambil dari populasi. Kaidah homogenitas jika $p>0,05$, maka tes dinyatakan homogen. Jika $p<$ 0,05 , maka tes dinyatakan tidak homogen. Dari hasil uji homogenitas penelitian ini dapat dilihat pada tabel berikut :

Tabel 9. hasil Uji Homogenitas

\begin{tabular}{|c|c|c|c|c|}
\hline Tes & $\mathrm{df1}$ & $\mathrm{df} 2$ & Sig & Keterangan \\
\hline $\begin{array}{c}\text { Pretest-Posttest Shooting } \\
\text { Sepakbola }\end{array}$ & 1 & 58 & 0,382 & Normal \\
\hline
\end{tabular}

Dari tabel di atas dapat dilihat nilai signifikasi (Sig) adalah 0,382

> 0,05 sehingga dapat disimpulkan bahwa variant data posttest latihan bola diam dan posttest latihan bola gerak adalah homogen. Oleh karenasemua data bersifat homogen maka analisis data ini dapat dilanjutkan dengan statistik parametrik.

\section{Hasil Uji Hipotesis}

Hipotesis dalam penelitian ini diuji menggunakan independent $t$ test dengan menggunakan bantuan SPSS 26, hasil uji hipotesis sebagai berikut: 
Perbedaan Pengaruh Metode Latihan dengan Bola Diam dan Bola Bergerak terhadap Ketepatan Shooting Sepakbola pada Pemain Putra Usia 10-12 Tahun SSB Bina Pratama Sragen Tahun 2020

(Adika Sukmawati ; Agus Supriyoko ; Fatkhul Imron)

Tabel 10. Hasil Uji Independent t-test Bola Diam dan Bola Gerak

\begin{tabular}{|c|c|c|c|c|c|c|c|c|c|c|}
\hline \multicolumn{11}{|c|}{ Independent Samples Test } \\
\hline & & \multicolumn{2}{|c|}{$\begin{array}{l}\text { Levene's } \\
\text { Test for } \\
\text { Equality } \\
\text { of } \\
\text { Variances }\end{array}$} & \multicolumn{7}{|c|}{ t-test for Equality of Means } \\
\hline & & \multirow[b]{2}{*}{$\mathrm{F}$} & \multirow[b]{2}{*}{ Sig. } & \multirow[b]{2}{*}{$\mathrm{t}$} & \multirow[b]{2}{*}{ Df } & \multirow{2}{*}{$\begin{array}{c}\text { Sig. } \\
(2- \\
\text { tailed } \\
1\end{array}$} & \multirow{2}{*}{$\begin{array}{c}\text { Mean } \\
\text { Differe } \\
\text { nce }\end{array}$} & \multirow{2}{*}{$\begin{array}{l}\text { Std. } \\
\text { Error } \\
\text { Diffe } \\
\text { rence }\end{array}$} & \multicolumn{2}{|c|}{$\begin{array}{c}95 \% \\
\text { Confidence } \\
\text { Interval of } \\
\text { the } \\
\text { Difference }\end{array}$} \\
\hline & & & & & & & & & $\begin{array}{c}\text { Lowe } \\
r\end{array}$ & $\begin{array}{c}\text { Upp } \\
\text { er }\end{array}$ \\
\hline $\begin{array}{c}\text { Hasil } \\
\text { shooti } \\
n g\end{array}$ & $\begin{array}{c}\text { Equal } \\
\text { variances } \\
\text { assumed }\end{array}$ & $\begin{array}{c}77 \\
9\end{array}$ & $\begin{array}{c}38 \\
1\end{array}$ & $\begin{array}{c}- \\
3,308\end{array}$ & 58 & ,002 & $-1,767$ & ,534 & $\begin{array}{c}- \\
2,836\end{array}$ & $\begin{array}{c}- \\
, 698\end{array}$ \\
\hline $\begin{array}{c}\text { sepak } \\
\text { bola }\end{array}$ & $\begin{array}{c}\text { Equal } \\
\text { variances } \\
\text { not } \\
\text { assumed }\end{array}$ & & & $\begin{array}{c}- \\
3,308\end{array}$ & $\begin{array}{c}56,88 \\
4\end{array}$ & ,002 & $-1,767$ & ,534 & $\begin{array}{c}- \\
2,836\end{array}$ & $\begin{array}{c}- \\
, 697\end{array}$ \\
\hline
\end{tabular}

Berdasarkan tabel di atas diketahui $t_{\text {hitung }}-3,308$ sedangkan pada

Sig. Levene's Test for Equallity of Variances adalah sebesar 0,381 >0,05 maka dapat diartikan bahwa variant data bola diam dan bola gerak bersifat sama. Pada bagian "Equal variances Assumed" diketahui nilai Sig. (2-tailed) sebesar 0,002 $<0,05$, maka dinyatakan $\mathrm{H}_{\mathrm{a}}$ diterima. Dengan demikian disimpulkan bahwa ada perbedaan yang signifikan (nyata) antara pretest dan posttest bola diam dan bola bergerak.

Untuk mengetahui kelompok mana yang memiliki presentase peningkatan yang lebih baik dapat diketahui dari tabel di bawah ini :

Tabel 11. Uji-t Hasil Pretest dan Posttest

\begin{tabular}{|l|c|c|c|c|c|c|}
\hline \multirow{2}{*}{ Kelompok } & \multirow{2}{*}{$\begin{array}{c}\text { Rata- } \\
\text { rata }\end{array}$} & \multicolumn{5}{|c|}{-test for Equality of means } \\
\cline { 3 - 7 } & t ht & $\mathbf{t}$ tb & Sig. & Selisih & $\%$ \\
\hline $\begin{array}{l}\text { Pretest bola } \\
\text { diam }\end{array}$ & 22,20 & 8,342 & 2,160 & 0,000 & 2,13 & $9,6 \%$ \\
\hline
\end{tabular}


Perbedaan Pengaruh Metode Latihan dengan Bola Diam dan Bola Bergerak terhadap Ketepatan Shooting Sepakbola pada Pemain Putra Usia 10-12 Tahun SSB Bina Pratama Sragen Tahun 2020

(Adika Sukmawati ; Agus Supriyoko ; Fatkhul Imron)

\begin{tabular}{|l|c|c|c|c|c|c|}
\hline $\begin{array}{l}\text { Posstest bola } \\
\text { diam }\end{array}$ & 24,33 & & & & & \\
\hline $\begin{array}{l}\text { Pretest bola } \\
\text { gerak }\end{array}$ & 22,00 & 6,548 & 2,160 & 0,000 & 1,40 & $6,3 \%$ \\
\hline $\begin{array}{l}\text { Posttest bola } \\
\text { gerak }\end{array}$ & 23,40 & & & & \\
\hline
\end{tabular}

Dari tabel di atas dapat diketahui bahwa metode latihan bola diam memiliki nilai peningkatan 9,6\%. Sedangkan metode latihan dengan bola bergerak memiliki peningkatan sebesar $6,3 \%$.

\section{Pengujian Hipotesis dan Pembahasan}

Hipotesis yang pertama berbunyi "Ada perbedaan pengaruh yang signifikan metode latihan dengan bola diam dan bola bergerak terhadap ketepatan shooting sepakbola pada pemain putra usia 10-12 tahun SSB Bina Pratama Sragen".Dari uji independent t-test menggunakan bantuan SPSS 26 mendapatkan thitung -3,308 dan t tabel 2,000, Karena nilai dari $\mathrm{t}$ hitung negatif, maka $\mathrm{t}$ hitung $-3,308<\mathrm{t}$ tabel 2,000, hasil ini menunjukkan terdapat perbedaan yang signifikan antara pretest dan posttest metode latihan bola diam dan bola bergerak. Dengan demikian hipotesis alternatif $\left(\mathrm{H}_{\mathrm{a}}\right)$ yang berbunyi "Ada perbedaan pengaruh yang signifikan antara metode latihan dengan bola diam dan latihan dengan bola bergerak terhadap ketepatan shooting sepakbola pada pemain putra usia 10-12 tahun SSB Bina Pratama Sragen" dinyatakan diterima.

Metode latihan bola diam memiliki presentase peningkatan kemampuan shooting sepakbola sebesar 9,6\%, Sedangkan metode latihan bola bergerak memiliki presentase peningkatan 6,3\%. Dengan demikian dapat disimpulkan bahwa metode latihan bola diam memiliki presentase yang lebih besar dari pada metode latihan bola bergerak. Dengan demikian hipotesis alternatif $\left(\mathrm{H}_{\mathrm{a}}\right)$ yang berbunyi, "Metode latihan shooting dengan bola diam lebih baik daripada bola bergerak terhadap 
Perbedaan Pengaruh Metode Latihan dengan Bola Diam dan Bola Bergerak terhadap Ketepatan Shooting Sepakbola pada Pemain Putra Usia 10-12 Tahun SSB Bina Pratama Sragen Tahun 2020

(Adika Sukmawati ; Agus Supriyoko ; Fatkhul Imron)

ketepatan shooting sepakbola pada pemain putra usia 10-12 tahun SSB

Bina Pratama Sragen" dinyatakan diterima.

\section{A. KESIMPULAN}

Berdasarkan hasil penelitian dan hasil analisis data yang dilakukan, dapat diperoleh simpulan sebagai berikut :

1. Ada perbedaan pengaruh yang signifikan antara metode latihan dengan bola diam dan latihan dengan bola bergerak terhadap ketepatan shooting sepakbola pada pemain putra usia 10-12 tahun SSB Bina Pratama Sragen tahun 2020. ( $t_{\text {hitung }}-3,308<t_{\text {tabel }} 2,000$ maka $H_{a}$ diterima $)$.

2. Metode latihan shooting dengan bola diam lebih baik daripada latihan dengan bola bergerak terhadap ketepatan shooting sepakbola pada pemain putra usia 10-12 tahun SSB Bina Pratama Sragen tahun 2020. (Metode latihan dengan bola diam mengalami peningkatan sebesar $9,6 \%$, sedangkan bola bergerak hanya mengalami peningkatan sebesar 6,3\% ).

\section{DAFTAR PUSTAKA}

Ali Maksum. 2012. Metodologi Penelitian dalam Olahraga. Surabaya: Unesa University Press-2012.

Ina Hasanah. 2019. Sepak Bola. Bandung: PT Indahjaya Adipratama.

Khafadi \& Sutrisno. 2010. Pendidikan Jasmani, Olahraga dan Kesehatan 2. Jakarta Pusat: Kementerian Pendidikan Nasional.

Luxbacher, J. A. 2011. Sepak Bola Langkah-Langkah Menuju Sukses. Alih Bahasa Agusta Wibawa. Jakarta: PT. Raja Grafindo.

Mulyono Biyakto Atmojo. 2008. Tes dan Pengukuran dalam Pendidikan Jasmani/Olahraga. Surakarta: LPP UNS dan UNS Press.

Sugiyono. 2007. Statistik untuk Penelitian. Bandung : Alfabeta,cv.

Sutrisno Hadi. 1995. Statistik II. Jakarta: PT. Rineka Cipta.

Wahyu Fajar Ihtiarini. 2017. Pengaruh Latihan Ladder Drill Two Feet Each Square dan Icky Shuffle Terhadap Kecepatan Gerak. Jurnal Kesehatan Olahraga. $7(3): 116$. 